\title{
CSR and Firm Reputation from Employee Perspective
}

\author{
Jannati TANGNGISALU ${ }^{1}$, M. MAPPAMIRING ${ }^{2}$, Wuryan ANDAYANI ${ }^{3}$, Muhammad YUSUF ${ }^{4}$, \\ Aditya Halim Perdana Kusuma PUTRA ${ }^{5}$
}

Received: July 18, 2020 Revised: August 23, 2020 Accepted: September 03, 2020

\begin{abstract}
This research focuses on the importance of corporate social responsibility in building the company's reputation. Experts have studied CSR as an antecedent of a company's reputation, but the mechanisms underlying this process are rarely explored. Therefore, to fill this research gap, we demonstrate CSR's implementation combined with organizational justice based on discrepancy and equity theory. This study involved 210 employees in a family company. The study's analysis method uses Structural Equation Model (SEM), SmartPLS, with a five-step measurement and analysis procedure. The variables in this study are CSR implementation, organizational justice, employee trust, firm reputation, organizational objectiveness, organizational commitment, job satisfaction, and job performance. The results found that some of the direct relationships stated were not significant, but all demonstrations of indirect links were substantial. Besides, optimal CSR and organizational justice provide a reliable and positive domino effect in increasing the role and consequences of employee trust and firm reputation. The findings in this study confirm that upstream-downstream job performance causality can be successfully achieved if job satisfaction has been realized, job satisfaction can be achieved if organizational commitment can also be recognized, and organizational commitment can be developed. Reflection and influence, rather than organizational attractiveness becomes essential.
\end{abstract}

Keywords: CSR, Reputation, Employee Trust, HRM Strategy

JEL Classification Code: E44, F31, F37, G15

\section{Introduction}

Intangible assets such as company reputation and employee trust are essential in an increasingly globalized business world. Indeed, intangible assets are critical achievements to determine the sustainability and success

${ }^{1}$ First Author and Corresponding Author. Associate Professor, Department of Management, STIEM Bongaya, Makassar, Indonesia [Postal Address: Let. Jend. Mappaouddang Street No.28, Bongaya, Makassar City, South Selatan 90131, Indonesia] Email: tanggisalu.bongaya@gmail.com

${ }^{2}$ Associate Professor. Department of Management, STIEM Bongaya, Makassar, Indonesia.

${ }^{3}$ Associate Professor. Faculty of Economic \& Business, Department of Accounting, Universitas Brawijaya Malang, East Java, Indonesia. ${ }^{4}$ Associate Professor. Faculty of Economic \& Business, Department of Management, Universitas Bosowa Makassar, Indonesia.

${ }^{5}$ Assistant Professor. Faculty of Economic \& Business, Department of Management, Universitas Muslim Indonesia, Makassar, Indonesia. Email: adityatrojhan@gmail.com

(c) Copyright: The Author(s)

This is an Open Access article distributed under the terms of the Creative Commons Attribution Non-Commercial License (https://creativecommons.org/licenses/by-nc/4.0/) which permits unrestricted non-commercial use, distribution, and reproduction in any medium, provided the original work is properly cited. of the business for the long-time. Company's reputation is defined as an impression that, as a whole, reflects the collective perception of stakeholder groups (Lai et al., 2010). One of the company's efforts to enhance its reputation among senior-level executives, in general, can be through the company's philanthropic activities (Williams \& Barrett, 2000). One of the company's philanthropy is reflected in the form of Corporate Social Responsibility (CSR) (Carroll \& Shabana, 2010). The concept of philanthropy illustrates that CSR integrates social and environmental care in business operations summarized in a voluntary cycle of business relationships with stakeholders. Philanthropy-based CSR has long been an essential and unique research target by many researchers who measure CSR implementation of various sizes and business activities of the company (Kechiche \& Soparnot, 2012).

The benefits of CSR have also been positively associated with evidence of the success of the entity. For example, such as financial performance (e.g., Yusoff, Mohamad, \& Darus, 2013; Gangi et al., 2018; Cormier \& Magnan, 2014), increased customer confidence (e.g., Marin, Ruiz, \& Rubio, 2009; van den Brink et al., 2006), massive and positive direct customer purchasing behavior (e.g., Mohr, Webb, 
\& Harris, 2001), increase in the level of full stakeholder confidence (e.g., Castaldo et al., 2009), increase in employee job satisfaction (Coldwell et al., 2008), and company appeal (e.g., Albinger \& Freeman, 2000; Jones, Willness, \& Madey, 2010; Maheshwari \& Yadav, 2015; Turban \& Greening, 1997). The domino effect of CSR, both on performance and socially, implies that CSR practices are able to take place and become powerful entities and indicators in determining the direction of sustainable business success (Málovics et al., 2008). In line with this, most of the research also discusses CSR, which focuses on direct relationships. Aguinis and Glavas (2012) examine the role of CSR in financial business results and performance. Then, prior research from another perspective more openly focused on discussing CSR's impact on external stakeholders rather than internal (employees) (e.g., Lee, Park, \& Lee, 2013; Raub \& Blunschi, 2014).

In this regard, we are confident to determine the novelty and standing position in reviewing CSR from different perspectives, thus filling the research gap, that has been developed by Rupp et al. (2006) who reviewed CSR's mechanism and implementation to help develop and optimize the company's trust and reputation in the eyes of its employees. The arrangements, assumptions, and terms of reference of our study focus on CSR perceptions. The first mechanism and reason are that employees' perceptions of CSR activities influence employee performance and steer organizational behavior for the better following CSR practices. Rupp et al. (2006) put the primary attention to be discussed on employee perceptions after the implementation of CSR. CSR implementation should ideally not only have an impact on the external sector of the business, but also must reflect positively on the internal side of the company. Implementation of CSR as much as possible can increase the confidence of employees (e.g., Collier \& Esteban, 2007; Hansen et al., 2011). The proposition that has been put forward by Rupp et al. (2006) states that the taxonomy of employee perceptions of CSR can be positive, negative, rational, or irrational if viewed from the perspective of organizational justice. So, it becomes a scientific and academic obligation to answer and confirm the proposition. Some relevant propositions that have been formulated by Rupp et al., (2006) include employee perceptions of CSR's implementation who will have a positive impact (e.g., organizational attractiveness, job satisfaction, organizational commitment, OCB, and job performance). Therefore, to be more comprehensive, our study will elaborate some references and perspectives such as CSR practices, organizational justice theories and strategies, and HRM practices. Figure 1 illustrates the description of the main problem and prior research agendas.

\section{Literature Review}

\subsection{CSR, Equity and Discrepancy Theory in Organization}

CSR refers to voluntary activities in which companies are involved to contribute to society and environment (GarcíaSánchez et al., 2019). The theoretical justification for CSR lies in the concept of being an unwritten contract between business and society in which a company is expected to fulfill specific social responsibility actions instead of the license or legitimacy obtained to operate (Ioannidou et al., 2014). There are three types and forms of CSR: the primary responsibilities of the company, namely, economic, social, and environmental responsibilities (Elkington, 1998). This type of ethical CSR focuses on fairness in practice that is based on moral principles (Carroll \& Shabana, 2010). This type of strategic CSR focuses on serving social services with several profit orientations for companies (Diouf \& Boiral, 2017). CSR philanthropy as a third type focuses on giving back to the community without any tendency (Carroll \& Shabana, 2010). Looking at the existing definition of CSR, it can be assumed that CSR is a system of voluntary activities carried out by the company to ensure the welfare of its stakeholders without compromising the long-term economic interests of the company. While the perceived effectiveness of CSR refers to the level of employee perceptions about the involvement given by their superiors fulfilling CSR obligations (Lii \& Lee, 2012). Most library studies use employee or customer perceptions to measure CSR. Employees' perceptions of CSR implementation lead to several positive organizational level outcomes, such as organizational commitment (Gond et al., 2017; Yang \& Kim, 2018).

Given the limitations to this study, we use equity and discrepancy theory. Both theories can be said to have meaning and goals to be achieved, namely, justice. All humans want to be treated fairly. Being treated fairly is something that everyone wants. John S. Adams was the first person to popularize the term justice or equality in organizations (equity theory). Adams stated that employees would maintain fairness between the input obligations they have done and the rights they receive. If the comparison is considered fair enough, it creates satisfaction, and injustice will trigger dissatisfaction. So, dissatisfaction becomes a motive for action for someone to uphold justice. Inequity also affects inequality. Locke coined discrepancy theory in 1969 (Rice et al., 1990). Locke explains that a person's job satisfaction depends on how much of a gap between hope and reality he or she achieves. In many ways, CSR is expressed by Elkington (1998) who states that CSR is beneficial for people, planet, and profit. The real organization's purpose is not only to generate profits, but also from the benefits 
that have been obtained. It can also provide benefits for the environment (planet) and the people. More in-depth than the CSR implementation, it also aims as a form of justice in the form of equality and to reduce the distortion of the gap.

\subsection{Prior Research}

Trust emphasizes relationships and influence. Trust is defined as a relationship where one party has trust in the reliability and integrity of the parties involved (Morgan \& Hunt, 1994). Trust can also be defined as a feeling of each party having a relationship that does not betray each another (Choudhury et al., 2007). Trust is recognized as an important element for the smooth functioning of the organization and for gaining legitimacy (Cho et al., 2015). Policy, fairness, and integrity are also found as materials needed to build that trust (Kim et al., 2014). Trust is also developed based on ethical judgment and organizational values (Lee et al., 2013). Signal theory and social-exchange theory help connect CSR perceptions with trust. CSR activities give rise to positive impressions by sending positive signals to employees regarding company ethics and values (Rupp et al., 2013). According to signal theory, a positive signal leads to increased employee confidence because companies that are considered to be involved in CSR activities tend to be identified as executors who act in the interests of all stakeholders, including employees inside the company (Mahoney et al., 2013). From the theory of social exchange predicts that the norm can regulate employee reactions. The positive perception of CSR is likely to increase employee confidence in their superiors because employees feel that the company has served the interests of all parties and deserves more trust from them. The overall perception of the company from each stakeholder can be defined as the company's reputation (Lai et al., 2010). Stakeholders provide an assessment of the company's reputation based on the signals they receive from the company (Brammer \& Pavelin, 2006). Besides, based on the financial performance and ownership of the company, signals based on philanthropic principles applied by the company's CSR also contribute positively to CSR perception (Wong \& Millington, 2014).

Trust and reputation of the company can be learned from the company's internal stakeholders; therefore, employees and external stakeholders are customers of the company. Keh and Xie (2009) found that a company's reputation can increase from the trust of customers formed in an organization. Besides, the trust of customers as an antecedent of the company's reputation (Walsh et al., 2009). This research assumes that the trust that is formed in employees is an antecedent of reputation rather than consequences. This trust is based on the reason that cognition influences attitude (Fishbein \& Ajzen, 1976). Trust itself can be conceptualized as a cognitive belief (Lee et al., 2013; Lai et al., 2010). Thus, increasing employee trust ideally leads to an increase in the company's reputation among its employees. Employee trust has been postulated to lead to positive attitudes, such as commitment and job satisfaction, and behavior, as a form of more effort made (Michaelis et al., 2009).

Concern about organizational justice has been a concern of HRM strategy experts for a long time (e.g., Bidarian \& Jafari, 2012; Wong, Ngo, \& Wong, 2006; Dong \& Phuong, 2018). Organizational justice concerns the aspects of distributive justice, procedural justice, and interactional justice (PérezRodríguez et al., 2019). Organizational justice is gaining in popularity in the 21 st century. It has attracted the interest of both experts and practitioners in the world of Human Resource Management (HRM) because it is useful as a critical element in the success of a competitive advantage strategy. Organizational justice has a positive impact on employee confidence (Bidarian $\&$ Jafari, 2012). The high level of trust formed by the fairness of an organization is fundamental in reducing conflict in the organization and increasing cooperative behavior (i.e., commitment and work effectiveness) (Wong et al., 2006). Some researchers have demonstrated the level of trust as a predictor to measure organizational commitment (Cook \& Wall, 1980), OCB (Konovsky, 2000; Dong \& Phuong, 2018), and work satisfaction (Bayarçelik \& Findikli, 2016; Islam et al., 2016). HRM managers are not only required to increase the productivity of their employees, more than that, but the vital role of internal company resources also requires primary attention.

In the development of the industrial world, employee psychology is a subject of study that HRM experts often discussed. One aspect is how to increase employee job satisfaction. HRM management is triggered by the presence of charges to pay more attention to the policies applied by the company to employees. Company policies that are not meeting the needs and expectations of employees will harm employees' work attitudes. Various studies have shown that employees who have positive work attitudes will be more productive than those with a negative attitude (e.g., Ouyang, Sang, Li, \& Peng, 2015; Lambert, Hogan, \& Griffin, 2007; McAuliffe et al., 2009). Workers who have a positive attitude towards work will have low absenteeism and resignation. The reciprocal relationship arising from job satisfaction will also positively impact employee commitment to the organization. Dedication to every employee is essential because, with a promise, an employee can be more responsible for his work than employees who do not commit to the work. Usually, employees with commitment will work optimally to devote their attention, thoughts, energy, and time to their work. So that what has been done is what was expected by the company. Thus, a strong commitment will reduce the intention to leave the company or turnover intention. Therefore, the hypotheses developed in this study are: 


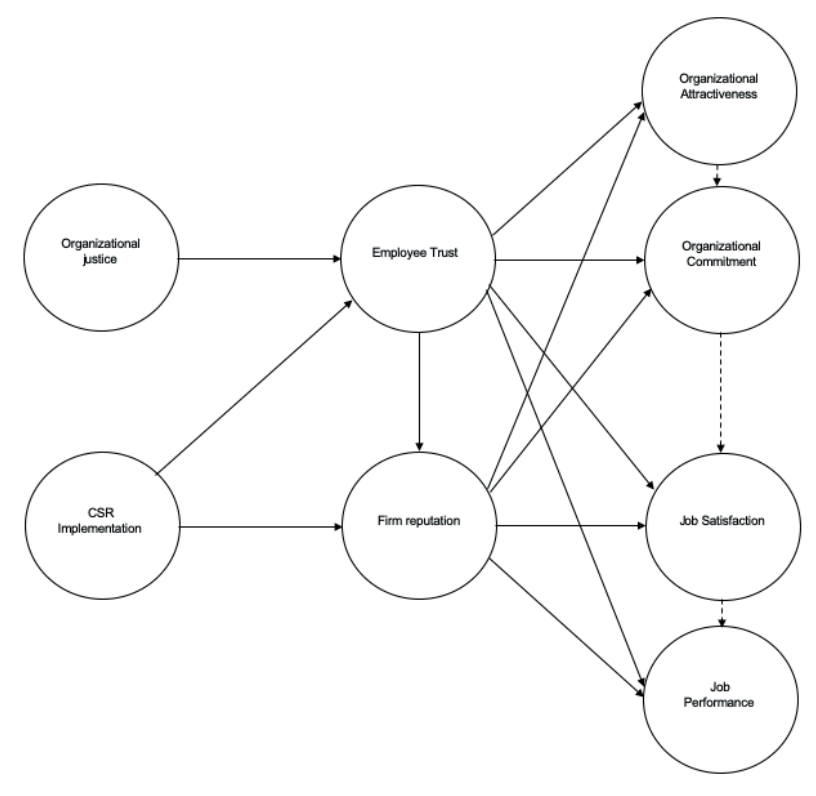

Figure 1: Research Model

H1: CSR implementation has both direct and indirect positive and significant impacts

H2: CSR implementation has positive and significant effects as variables that strengthen the optimization of employee trust, firm reputation, organizational attractiveness, organizational commitment, job satisfaction, and job performance.

$\boldsymbol{H} 3:$ Variable firm employee trust and reputation can be pure antecedent variable, in consequence, a decisive role in improving organizational attractiveness, organizational commitment, job satisfaction, and job performance

H4: CSR implementation that is in line with the optimal application of organizational justice provides a positive domino effect in strengthening and increasing organizational attractiveness, organizational commitment, job satisfaction, and job performance.

H5: Systematic job performance can be generated if job satisfaction, organizational commitment, and organizational attractiveness are fulfilled.

\section{Research Methods and Materials}

\subsection{Data}

The subjects in this study consisted of a single data from family businesses operating in the Makassar City, South Sulawesi, Indonesia, since 1952. The family company has eight business sectors with 24 business sub-units that are actively engaged and enter the ranks of the large national companies in Indonesia in the category of family companies. Their business units include automotive, finance, construction, transportation and logistics, energy, property, retail, forestry, foundations, education, religion, society, and the environment. We distribute questionnaires to 210 employees in $60 \%$ of their business units. The minimum work experience in the sample is seven months, while the maximum is 456 months, with a total average work experience of 35.4 months. Of the 210 responses as many as 117 people $(55.71 \%)$ were in the middle management (supervisors, senior employees, and managers), and 93 answers came from the low-management category (i.e., operators, junior employees and technicians). From the highest educated group, 52 respondents had master's degrees, and 65 respondents had a bachelor or diploma degrees. Ninety-three respondents came from a vocational school and high school. Some 130 respondents are married, and 80 are single. From the age factor, the largest group of respondents is aged between 25 and 48 .

\subsection{Procedure and Measurement}

Data collection use surveys, each item is measured on a 5-point Likert scale ( $1=$ Totally Disagree; 2 = Disagree; $3=$ Neutral; 4 = Agree; $5=$ Totally Agree). The testing procedure is divided into five scenarios: Scenario I is testing CSR implementation variables through direct and indirect testing. Scenario II is testing organizational justice variables through direct and indirect testing. Scenario III is a direct and indirect test by making the employee trust (ET) variable an antecedent variable. Scenario IV is a direct and indirect test by making the firm reputation (FR) variable an antecedent variable. Scenario $\mathrm{V}$ is a chain of organizational attractiveness 
(OA), organizational commitment (OC), job satisfaction (JS) and job performance (JP) variables.

The total variables in this study consist of eight variables, namely, two independent variables, i.e., organizational justice (OJ) and CSR implementation (CSR), two intervening variables as well as the dependent variable, and the antecedent variable in scenario II and scenario III, i.e., employee trust (ET) and firm reputation (FR), and four pure dependent variables as in Scenarios IV and V, i.e., organizational attractiveness (OA), organizational commitment (OC), job satisfaction (JS) and job performance (JP). The details are illustrated in Figure 1 . The system of measuring variables with a total of 44 (fortyfourth questions) is explained in Table 1. The questionnaire consists of 11 questions for organizational justice (OJ) variables that refer to the study (e.g., Haerani et al., 2020; Akram et al., 2020; Wulani, 2007). There are 10 questions for the CSR implication (CSR) variable referring to the study (e.g., Mohr, Webb, \& Harris, 2001; Rupp et al., 2006). Seven questions refer to employee trust (ET) variables and three questions to organizational commitment (OC) variables referring to the study (e.g., Morgan \& Hunt, 1994; Rupp et al., 2006). Three questions refer to firm reputation (FR) variables (Lai et al., 2010; Rupp et al., 2006). Ten questions refer to organizational attractiveness (OA), job satisfaction (JS) and job performance (JP) variables (e.g., Rupp et al., 2006; Brunner \& Baum, 2020; Park et al., 2020; Nguyen, 2020).

The approach and method of analysis in this study uses the Structural Equation Model (SEM) with statistical tools using SmartPLS; confirmation of the relationship between variables is also carried out as in the predetermined analysis scenarios. The measurement standard of data analysis is carried out through several stages, namely, the model feasibility test (GoF, AVE, and discriminant validity, reliability tests such as Cronbach's Alpha, composite reliability, VIF test). Hypothesis testing and influence testing are processed through the bootstrapping stage to determine the value of the t-test coefficient and the significance coefficient value.

\section{Results and Discussion}

\subsection{Statistical Results}

Table 1 shows the distribution and responses of respondents where the average distribution of questionnaires is at the strong level of agreement with all statements (3.62 - 4.11).

Table 2 shows the normality, validity, reliability, and determination of variables. All items are valid and reliable to make the latent variable loading value, AVE, Cronbach's Alpha $(\alpha)$, Composite Reliability $(C R)>0.60$. The results of statistical tests using SmartPLS with algorithmic methods to measure the inner and outer models, as illustrated in Table 2, concluded that all constructs in arranging variables are valid and reliable. Then, in the goodness fit of model testing the test value is $\mathrm{SRMR}=0.067<0.08 ; \mathrm{NFI}=0.975>0.90 ; \mathrm{d}$ uls $=4,444$; Chi-Square $=209,657$. The results of the SEMPLS Model are also illustrated in Figure 2.

The results depicted in Table 3 show that, of the 39 path-lines in the SEM model demonstration that are dominantly positive and significant, only six lines are declared insignificant (e.g., line-2, line-23, line-24, line-27, line-28 and line-33). The six path-lines do not contribute significantly to the relationships between variables directly. So, it can be concluded that the insignificant relationship between variables directly illustrates that the SEM model variation model requires other variables both as intervening variables, moderating variables, and mediating variables.

Therefore, in this section, we also describe the hypotheses issued from the literature review section, which are stated as research results:

- Hypothesis 1: all demonstrations of the relationship of CSR implementation variables with a total of 10 demonstrations, six direct demonstration, have positive and significant effects. The relationship that has the most dominant effect is that which describes the variable relationship between CSR implementation on employee trust, while the direct link between CSR implementation on firm reputation is unsupported. On the other hand, demonstration models that illustrate indirect relationships' situation by making employee trust and firm reputation as mediating and intervening variables have a positive and significant effect.

- Hypothesis 2: CSR implementation further strengthens the relationship between employee trust and firm reputation on organizational attractiveness, organizational commitment, job satisfaction, and job performance. It can also be assumed that CSR implementation manifests opportunities to increase employee trust and firm reputation.

- Hypothesis 3: Employee trust variables cannot always be pure antecedent variables in measuring the consequences of organizational attractiveness, organizational commitment, job satisfaction, and job performance. This is evidenced by the fact that the direct relationship (e.g., path-lines 23, 24, 27 , and path-line 28) has no significant effect. In conclusion, the employee trust variable is suitable as an intervening, moderating, or mediating variable rather than a pure manifest/antecedent variable. Inversely proportional to the variable firm reputation, the dominant demonstration of relationship variables (path-line) has a positive and significant effect both directly and indirectly. So, it can be concluded that the firm reputation variable can be an antecedent variable to measure the latent dependent variable's consequences. 
Table 1: Variable Measurement Result

\begin{tabular}{|c|c|c|c|c|c|c|c|}
\hline Code & Item / Indicator / Variables & Mean & \begin{tabular}{|c|} 
Std. \\
Error \\
\end{tabular} & \begin{tabular}{|l|} 
Std. \\
Dev
\end{tabular} & \begin{tabular}{|l|} 
Loading \\
Factor
\end{tabular} & VIF & $\mathbf{R}^{2}$ \\
\hline \multicolumn{8}{|c|}{ Organizational Justice (Distributive, Procedural, Temporal, Interactional and Spatial) } \\
\hline OJ1 & - Employment fairness and salary & 4,09 & 0,06 & 0,82 & 0,767 & 2,393 & \multirow{11}{*}{-} \\
\hline OJ2 & - Old working justice and salary & 3,84 & 0,06 & 0,87 & 0,738 & 1,964 & \\
\hline OJ3 & - Long-serving justice and position & 4,09 & 0,05 & 0,80 & 0,728 & 2,049 & \\
\hline OJ4 & - Reward and punishment according to SOP & 3,99 & 0,06 & 0,87 & 0,784 & 2,336 & \\
\hline OJ5 & - Work evaluation is done transparently & 4,06 & 0,06 & 0,88 & 0,755 & 2,166 & \\
\hline OJ6 & - Fairness and suitability of organizational working hours & 4,02 & 0,06 & 0,91 & 0,808 & 2,469 & \\
\hline OJ7 & - Having free time to enjoy life & 3,73 & 0,07 & 0,94 & 0,767 & 2,592 & \\
\hline OJ8 & - Perception of respect, politeness, and dignity & 4,00 & 0,06 & 0,90 & 0,790 & 2,449 & \\
\hline OJ9 & - Fair treatment in Action and decision making & 3,85 & 0,07 & 0,96 & 0,821 & 2,030 & \\
\hline OJ10 & - The right and justice to express an opinion & 3,85 & 0,07 & 0,96 & 0,788 & 2,651 & \\
\hline OJ11 & - Free of racism issues & 4,08 & 0,06 & 0,87 & 0,770 & 2,274 & \\
\hline \multicolumn{8}{|c|}{ CSR Implementation (Morality aspect, Philanthropy aspect, Environment aspect) } \\
\hline CSR1 & - CSR impacts the moral aspects of the company to the community & 3,69 & 0,06 & 0,94 & 0,633 & 1,641 & \\
\hline CSR2 & - Fulfilling CSR raises employee morality towards the company & 3,77 & 0,05 & 0,78 & 0,709 & 2,224 & \\
\hline CSR3 & - Company discipline in fulfilling CSR obligations & 3,72 & 0,06 & 0,82 & 0,722 & 2,182 & \\
\hline CSR4 & - CSR is a corporate obligation & 3,62 & 0,06 & 0,89 & 0,709 & 1,877 & \\
\hline CSR5 & - Corporate CSR is done voluntarily without any tendency & 3,86 & 0,06 & 0,80 & 0,759 & 2,198 & \\
\hline CSR6 & - CSR that fluctuates with the level of profit increase & 4,11 & 0,06 & 0,84 & 0,732 & 2,155 & \\
\hline CSR7 & - The company's concern for the surrounding business environment & 4,22 & 0,06 & 0,81 & 0,832 & 3,017 & \\
\hline CSR8 & - Application of CSR to social (religion, education, health) & 4,09 & 0,05 & 0,78 & 0,748 & 2,161 & \\
\hline CSR9 & - The application of CSR to the sustainability of natural resources & 3,96 & 0,06 & 0,81 & 0,807 & 2,143 & \\
\hline CSR10 & - Application of CSR to improving the standard of living of the community & 4,13 & 0,05 & 0,80 & 0,773 & 1,641 & \\
\hline \multicolumn{8}{|c|}{ Employee Trust } \\
\hline ET1 & - The purpose of CSR increases employee confidence in the company & 3,92 & 0,06 & 0,85 & 0,833 & 2,397 & \multirow{7}{*}{0.754} \\
\hline ET2 & - Employee trust increases due to the transparency of financial statements & 4,00 & 0,06 & 0,90 & 0,791 & 2,153 & \\
\hline ET3 & - The company's concern is not only with CSR but also the fate of employees & 3,91 & 0,05 & 0,79 & 0,776 & 2,007 & \\
\hline ET4 & - Honesty of the company in reporting CSR & 3,98 & 0,06 & 0,89 & 0,835 & 2,459 & \\
\hline ET5 & - Positive appreciation of the organization in line with the CSR activity & 3,92 & 0,06 & 0,83 & 0,803 & 2,238 & \\
\hline ET6 & - Company integrity towards CSR & 3,82 & 0,06 & 0,90 & 0,835 & 2,642 & \\
\hline ET7 & - The company's management integrity of employees & 3,84 & 0,06 & 0,85 & 0,794 & 2,264 & \\
\hline \multicolumn{8}{|c|}{ Firm Reputation } \\
\hline FR1 & - Positive customer ratings for the company are good & 4,10 & 0,06 & 0,87 & 0,847 & 1,777 & \multirow{3}{*}{0.711} \\
\hline FR2 & - Positive competitive ratings of the company are good & 3,95 & 0,07 & 0,97 & 0,875 & 1,970 & \\
\hline FR3 & - Customers believe the company can be sustainable long term & 3,93 & 0,06 & 0,90 & 0,848 & 1,772 & \\
\hline \multicolumn{8}{|c|}{ Organizational Attractiveness } \\
\hline OA1 & - The company is a prestigious place to work & 3,70 & 0,07 & 0,98 & 0,907 & 1,793 & \multirow{2}{*}{0.563} \\
\hline OA2 & - This type of work is desirable to employees & 3,88 & 0,07 & 1,00 & 0,918 & 1,793 & \\
\hline \multicolumn{8}{|c|}{ Organizational Commitment } \\
\hline OC1 & - Employee work commitment & 3,99 & 0,07 & 0,94 & 0,880 & 2,148 & \multirow{3}{*}{0.744} \\
\hline $\mathrm{OC2}$ & - Intention to stay & 3,74 & 0,07 & 1,06 & 0,898 & 2,303 & \\
\hline $\mathrm{OC} 3$ & - Cooperative action towards the company & 4,11 & 0,05 & 0,78 & 0,833 & 1,737 & \\
\hline \multicolumn{8}{|c|}{ Job satisfaction } \\
\hline JS1 & - Good work environment & 4,06 & 0,06 & 0,85 & 0,873 & 2,186 & \multirow{5}{*}{0.656} \\
\hline JS2 & - Job suitability and competence & 4,14 & 0,06 & 0,83 & 0,891 & 1,510 & \\
\hline JS3 & - Appropriate salary & 4,21 & 0,06 & 0,83 & 0,878 & 1,896 & \\
\hline JS4 & - Good teamwork & 4,17 & 0,06 & 0,86 & 0,897 & 2,509 & \\
\hline JS5 & - Fair leadership & 3,96 & 0,06 & 0,89 & 0,812 & 2,266 & \\
\hline \multicolumn{8}{|c|}{ Job Performance } \\
\hline JP1 & - Improved quality of discipline & 4,04 & 0,06 & 0,89 & 0,926 & 2,394 & \multirow{3}{*}{0.683} \\
\hline JP2 & - Improved quality and quantity of work & 3,94 & 0,06 & 0,91 & 0,903 & 2,175 & \\
\hline JP3 & - Job responsibilities & 3,97 & 0,07 & 1,08 & 0,683 & 1,431 & \\
\hline
\end{tabular}


Table 2: Goodness of Fit Data and Model

\begin{tabular}{|c|c|c|c|c|c|c|c|c|c|}
\hline \multicolumn{5}{|c|}{ Variable } & $\begin{array}{c}\text { Cronbach } \\
\text { Alpha }\end{array}$ & Rho_A & $\begin{array}{l}\text { Composite } \\
\text { Reliability }\end{array}$ & AVE & Conclusion \\
\hline \multicolumn{5}{|c|}{ Organizational Justice (OJ) } & 0.933 & 0.934 & 0.943 & 0.630 & \multirow{8}{*}{ Reliable } \\
\hline \multicolumn{5}{|c|}{ CSR Implementation (CSR) } & 0.910 & 0.916 & 0.925 & 0.654 & \\
\hline \multicolumn{5}{|c|}{ Employee Trust (ET) } & 0.913 & 0.915 & 0.930 & 0.656 & \\
\hline \multicolumn{5}{|c|}{ Firm Reputation (FR) } & 0.819 & 0.820 & 0.892 & 0.734 & \\
\hline \multicolumn{5}{|c|}{ Organizational Attractiveness (OA) } & 0.799 & 0.800 & 0.909 & 0.832 & \\
\hline \multicolumn{5}{|c|}{ Organizational Commitment (OC) } & 0.840 & 0.844 & 0.904 & 0.758 & \\
\hline \multicolumn{5}{|c|}{ Job Satisfaction (JS) } & 0.920 & 0.921 & 0.940 & 0.758 & \\
\hline \multicolumn{5}{|c|}{ Job Performance (JP } & 0.804 & 0.878 & 0.882 & 0.717 & \\
\hline \multicolumn{10}{|c|}{ Discriminant Validity - Fornell Larcker } \\
\hline & CSR & ET & FR & JP & JS & OA & OC & OJ & Conclusion \\
\hline CSR & 0.744 & & & & & & & & \multirow{8}{*}{ Valid } \\
\hline ET & 0.840 & 0.810 & & & & & & & \\
\hline FR & 0.759 & 0.839 & 0.857 & & & & & & \\
\hline $\mathrm{JP}$ & 0.516 & 0.540 & 0.640 & 0.846 & & & & & \\
\hline JS & 0.622 & 0.674 & 0.744 & 0.826 & 0.871 & & & & \\
\hline $\mathrm{OA}$ & 0.661 & 0.705 & 0.735 & 0.637 & 0.768 & 0.912 & & & \\
\hline $\mathrm{OC}$ & 0.708 & 0.768 & 0.784 & 0.679 & 0.787 & 0.809 & 0.871 & & \\
\hline OJ & 0.841 & 0.829 & 0.814 & 0.588 & 0.673 & 0.701 & 0.729 & 0.775 & \\
\hline
\end{tabular}

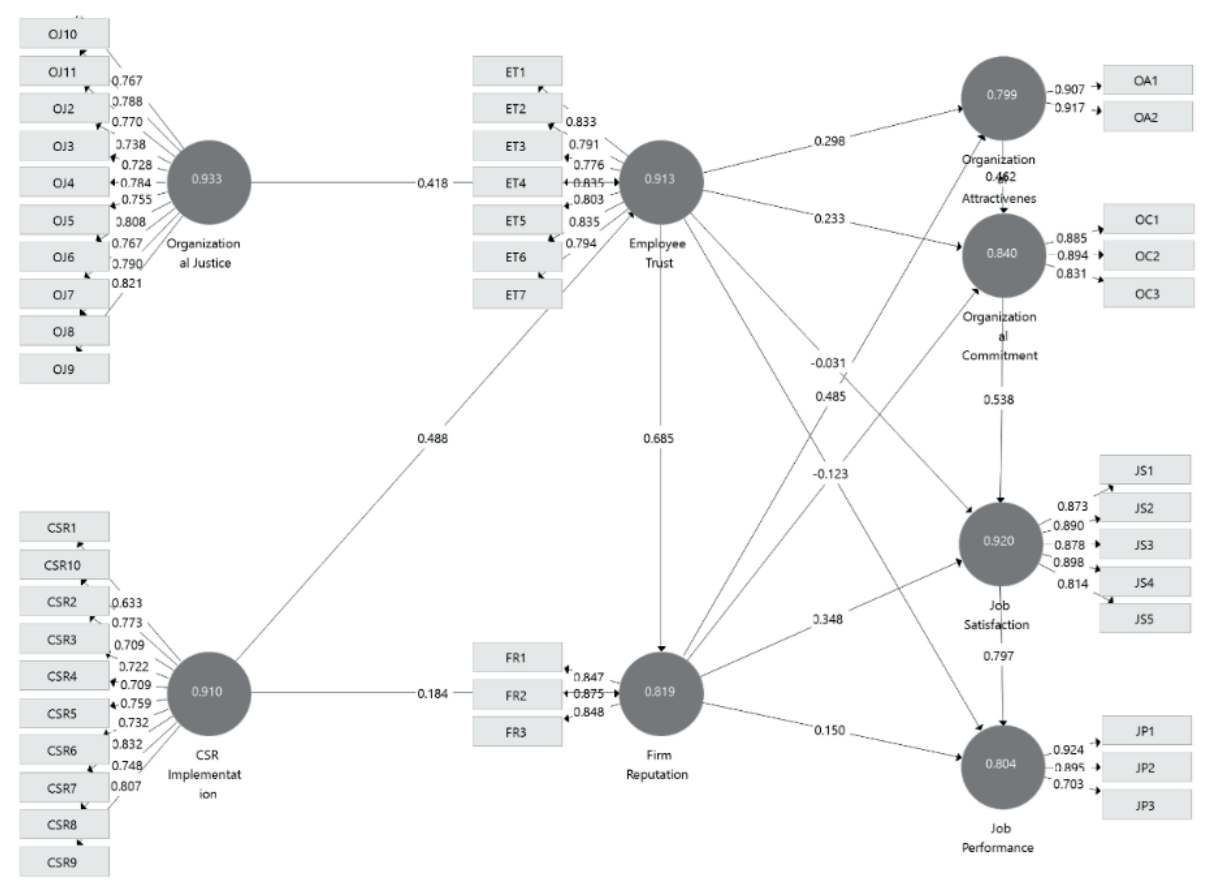

Figure 2: Structural Equation Model-PLS 
Table 3: Hypotheses Results

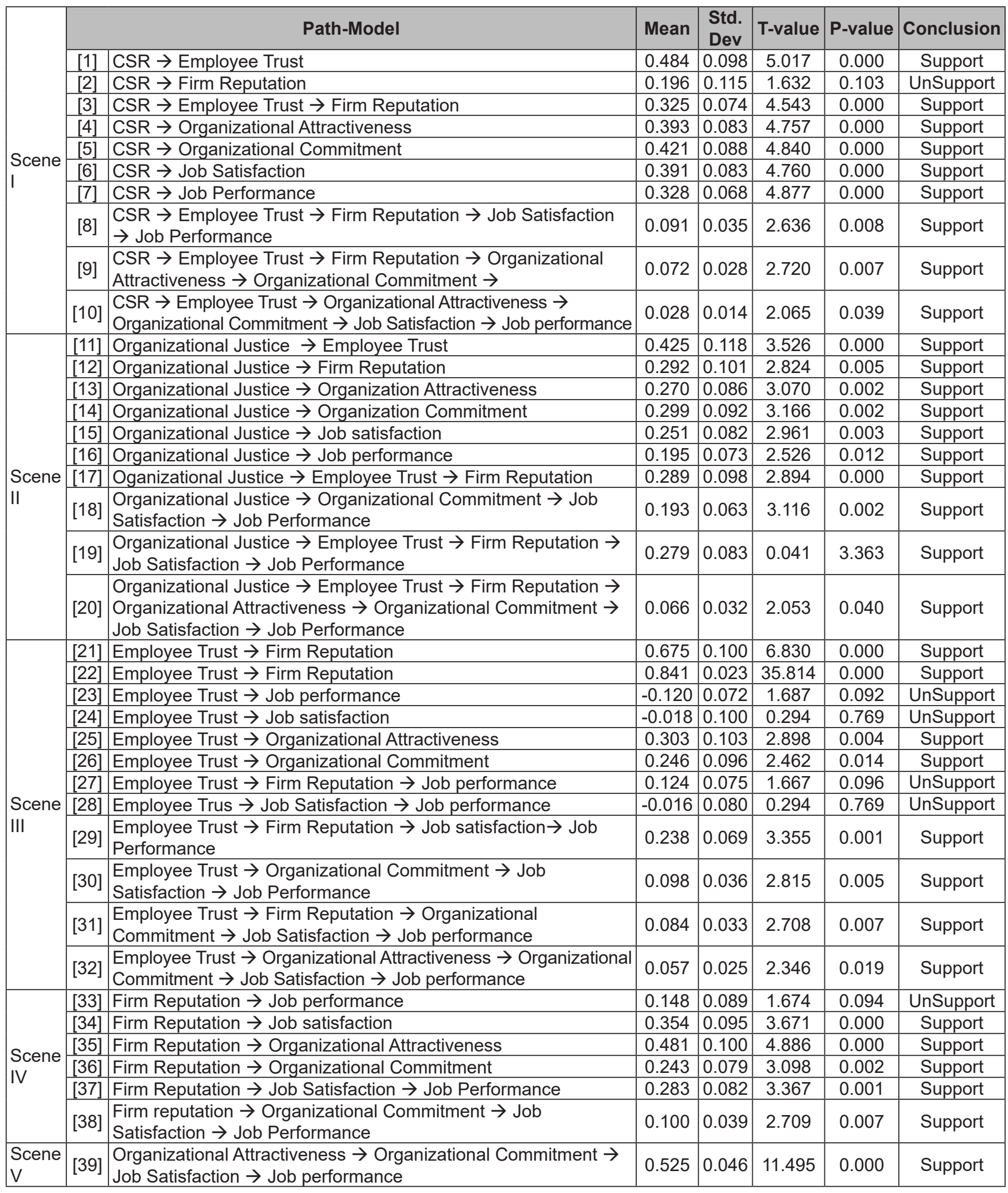


- Hypothesis 4: Optimal CSR implementation and organizational justice have a strong and positive domino effect in increasing the role and consequence of complete employee trust and firm reputation. As a result, proper CSR implementation and organizational justice also have broad impacts on organizational attractiveness, organizational commitment, job satisfaction, and job performance.

- Hypothesis 5: The findings of this study also confirm that upstream-downstream job performance causality can be successfully achieved if job satisfaction has been realized, job satisfaction can be accomplished if organizational commitment can also be recognized, and to develop organizational commitment, reflection and influence rather than organizational attractiveness becomes vital.

\subsection{Discussion}

The model we have demonstrated provides empirical evidence that the interrelationship between CSR practices has a positive impact on the company's outside interests and has a domino effect on the organization's internal, growing and optimizing employee trust and company reputation. The effect of morality caused by CSR practices will also raise employee morality in the eyes of their environment. CSR practices carried out consistently, transparently, and without tendency (philanthropy) are at the core of sustainable CSR management and strategies to obtain optimal reputation and perfect employee trust. Of course, our study also underlines that CSR practices are not only limited to aspects of social responsibility, as previous studies have discussed it (e.g., social responsibility, economic responsibility, and corporate responsibility) as echoed by Elkington, (1998). In our study, we assess CSR practices as an excellent corporate strategy in practice to grow and maintain a company's image to the practice of morality in developing human resource strategies (CSR as a strategy). Some propositions that have been discussed by Rupp et al. (2006) have also been answered in our study. Among the announced propositions, we also find that the relationship between CSR practices has a positive and significant impact, not only on the level of employee confidence in the company, but also directly related to employee satisfaction and performance. On the other hand, we also consider that the CSR practice factor must be supported by organizational justice. We also assess that the regulatory justice factor in line with transparent CSR practices is the perfect mix in a combination of HRM strategies. Some of the demonstrations and research hypotheses and models are shown in Figures 2 and 3. We provided confirmations that have direct effects, and some variable relationships are not significant until we conclude that the antecedents of organizational justice and CSR implementation have real and positive effects. As regards the level of organizational justice, there is a good feeling between what employees feel both in the form of increased employee value and employee size, both morally and materially.

As for theoretical and managerial implications, CSR implementation has a positive effect on fostering employee trust and also the company's reputation. In practice, for CSR management, the main requirements are consistency and transparency. CSR implementation that is in line with the perception of organizational justice can have positive and significant effects and can also be a corporate strategy to maintain the company's reputation and optimize human resource management in HRM practices.

\section{Conclusions}

In this study model, organizational justice based on discrepancy and equity theory provides a clear picture to deliver positive CSR practices as a solid building to enhance reputation both externally and internally. In other words, transparent CSR implementation and the link between company reputation and company performance can be optimal as long as the level of employee trust is also obtained. Transparent CSR and optimal organizational justice will shape the perception that the level of collectivism in management practices is low. The findings of this study also confirm that upstream-downstream job performance causality can be successfully achieved if job satisfaction has been realized, job satisfaction can be accomplished if organizational commitment can also be recognized, and to develop organizational commitment, reflection and influence rather than organizational attractiveness becomes vital.

\section{References}

Aguinis, H., \& Glavas, A. (2012). What We Know and Don't Know About Corporate Social Responsibility. Journal of Management, 38(4), 932-968. https://doi.org/10.1177/0149206311436079

Akram, T., Lei, S., Haider, M. J., \& Hussain, S. T. (2020). The impact of organizational justice on employee innovative work behavior: Mediating role of knowledge sharing. Journal of Innovation \& Knowledge, 5(2), 117-129. https://doi.org/https:// doi.org/10.1016/j.jik.2019.10.001

Albinger, H. S., \& Freeman, S. J. (2000). Corporate Social Performance and Attractiveness as an Employer to Different Job Seeking Populations. Journal of Business Ethics, 28(3), 243-253. https://doi.org/10.1023/A:1006289817941

Bayarçelik, E. B., \& Findikli, M. A. (2016). The Mediating Effect of Job Satisfaction on the Relation Between Organizational Justice Perception and Intention to Leave. Procedia - Social and Behavioral Sciences, 235, 403-411. https://doi.org/https:// doi.org/10.1016/j.sbspro.2016.11.050

Bidarian, S., \& Jafari, P. (2012). The Relationship Between Organizational Justice and Organizational Trust. Procedia - 
Social and Behavioral Sciences, 47, 1622-1626. https://doi.org/ https://doi.org/10.1016/j.sbspro.2012.06.873

Brammer, S. J., \& Pavelin, S. (2006). Corporate Reputation and Social Performance: The Importance of Fit. Journal of Management Studies, 43(3), 435-455. https://doi.org/10.1111/ j.1467-6486.2006.00597.x

Brunner, C. B., \& Baum, M. (2020). The impact of brand portfolios on organizational attractiveness. Journal of Business Research, 106, 182-195. https://doi.org/https://doi.org/10.1016/j. jbusres.2019.09.014

Carroll, A. B., \& Shabana, K. M. (2010). The Business Case for Corporate Social Responsibility: A Review of Concepts, Research and Practice. International Journal of Management Reviews, 12(1), 85-105. https://doi.org/10.1111/j.14682370.2009.00275.x

Castaldo, S., Perrini, F., Misani, N., \& Tencati, A. (2009). The Missing Link Between Corporate Social Responsibility and Consumer Trust: The Case of Fair Trade Products. Journal of Business Ethics, 84(1), 1-15. https://doi.org/10.1007/s10551008-9669-4

Cho, C. H., Michelon, G., Patten, D. M., \& Roberts, R. W. (2015). CSR disclosure: The more things change...? Accounting, Auditing and Accountability Journal, 28(1), 14-35. https://doi. org/10.1108/AAAJ-12-2013-1549

Choudhury, M. A., Zaman, S. I., \& Harahap, S. S. (2007). An Evolutionary Topological Theory of Participatory Socioeconomic Development. World Futures, 63(8), 584-598. https://doi.org/10.1080/02604020701681219

Coldwell, D. A., Billsberry, J., van Meurs, N., \& Marsh, P. J. G. (2008). The Effects of Person-Organization Ethical Fit on Employee Attraction and Retention: Towards a Testable Explanatory Model. Journal of Business Ethics, 78(4), 611622. https://doi.org/10.1007/s10551-007-9371-y

Collier, J., \& Esteban, R. (2007). Corporate social responsibility and employee commitment. Business Ethics: A European Review, 16(1), 19-33. https://doi.org/10.1111/j.14678608.2006.00466.x

Cook, J., \& Wall, T. (1980). New work attitude measures of trust, organizational commitment and personal need non-fulfilment. Journal of Occupational Psychology, 53(1), 39-52. https://doi. org/10.1111/j.2044-8325.1980.tb00005.x

Cormier, D., \& Magnan, M. (2014). The impact of social responsibility disclosure and governance on financial analysts' information environment. Corporate Governance: The International Journal of Business in Society, 14(4), 467-484. https://doi.org/10.1108/CG-01-2013-0012

Diouf, D., \& Boiral, O. (2017). The quality of sustainability reports and impression management: A stakeholder perspective. Accounting, Auditing and Accountability Journal, 30(3), 643667. https://doi.org/10.1108/AAAJ-04-2015-2044

Dong, L. N. T., \& Phuong, N. N. D. (2018). Organizational justice, job satisfaction and organizational citizenship behavior in higher education institutions: A research proposition in Vietnam.
Journal of Asian Finance, Economics and Business, 5(3), 113119. https://doi.org/10.13106/jafeb.2018.vol5.no3.113

Elkington, J. (1998). Partnerships fromcannibals with forks: The triple bottom line of 21st-century business. Environmental Quality Management, 8(1), 37-51. https://doi.org/10.1002/ tqem.3310080106

Elkington, J. (2013). Enter the triple bottom line. In: The triple bottom line (pp. 23-38). Abingdon, UK: Routledge.

Fishbein, M., \& Ajzen, I. (1976). Misconceptions about the Fishbein model: Reflections on a study by Songer-Nocks. Journal of Experimental Social Psychology, 12(6), 579-584. https://doi. org/10.1016/0022-1031(76)90036-6

Gangi, F., Mustilli, M., Varrone, N., \& Daniele, L. M. (2018). Corporate Social Responsibility and Banks' Financial Performance. International Business Research, 11(10), 42-58. https://doi.org/10.5539/ibr.v11n10p42

García-Sánchez, I.-M., Hussain, N., Martínez-Ferrero, J., \& RuizBarbadillo, E. (2019). Impact of disclosure and assurance quality of corporate sustainability reports on access to finance. Corporate Social Responsibility and Environmental Management, 26(4), 832-848. https://doi.org/10.1002/ csr. 1724

Gond, J.-P., El Akremi, A., Swaen, V., \& Babu, N. (2017). The psychological microfoundations of corporate social responsibility: A person-centric systematic review. Journal of Organizational Behavior, 38(2), 225-246. https://doi. org/10.1002/job.2170

Goodsell, C. T. (2006). A New Vision for Public Administration. Public Administration Review, 66(4), 623-635. https://doi. org/10.1111/j.1540-6210.2006.00622.x

Haerani, S., Sumardi, Hakim, W., Hartini, \& Putra, A. H. P. K. (2020). Structural Model of Developing Human Resources Performance: Empirical Study of Indonesia States Owned Enterprises. Journal of Asian Finance, Economics and Business, 7(3), 211-221. https://doi.org/10.13106/jafeb.2020. vol7.no3.211

Hansen, S. D., Dunford, B. B., Boss, A. D., Boss, R. W., \& Angermeier, I. (2011). Corporate Social Responsibility and the Benefits of Employee Trust: A Cross-Disciplinary Perspective. Journal of Business Ethics, 102(1), 29-45. https://doi. org/10.1007/s10551-011-0903-0

Huseman, R. C., Hatfield, J. D., \& Miles, E. W. (1987). A new perspective on equity theory: The equity sensitivity construct. Academy of Management Review, 12(2), 222-234.

Ioannidou, E., Kipouros, A., Tsourgiannis, L., \& Simet, G. F. (2014). Corporate Social Responsibility in Greek Banking Sector - An Empirical Research. Procedia Economics and Finance, 9, 193199. https://doi.org/10.1016/S2212-5671(14)00020-3

Islam, Z., Bangish, S. B., Muhammad, H., \& Jehan, A. S. (2016). The Impact of HR Practices on Job satisfaction: A Case Study of Hotel Industry in Pakistan. Journal of Asian Finance, Economics and Business, 3(1), 43-48. https://doi.org/10.13106/ jafeb.2016.vol3.no1.43. 
Jones, D. A., Willness, C. R., \& Madey, S. (2010). Why are job seekers attracted to socially responsible companies? testing underlying mechanisms. Academy of Management Proceedings, 2010(1), 1-6. https://doi.org/10.5465/ ambpp.2010.54501146

Kechiche, A., \& Soparnot, R. (2012). CSR within SMEs: Literature Review. International Business Research, 5(7), 97-104. https:// doi.org/10.5539/ibr.v5n7p97

Keh, H. T., \& Xie, Y. (2009). Corporate reputation and customer behavioral intentions: The roles of trust, identification and commitment. Industrial Marketing Management, 38(7), 732742. https://doi.org/10.1016/j.indmarman.2008.02.005

Kim, Y., Li, H., \& Li, S. (2014). Corporate social responsibility and stock price crash risk. Journal of Banking \& Finance, 43, 1-13. https://doi.org/10.1016/j.jbankfin.2014.02.013

Konovsky, M. A. (2000). Understanding Procedural Justice and Its Impact on Business Organizations. Journal of Management, 26(3), 489-511. https://doi.org/10.1177/014920630002600306

Lai, C.-S., Chiu, C.-J., Yang, C.-F., \& Pai, D.-C. (2010). The Effects of Corporate Social Responsibility on Brand Performance: The Mediating Effect of Industrial Brand Equity and Corporate Reputation. Journal of Business Ethics, 95(3), 457-469. https:// doi.org/10.1007/s10551-010-0433-1

Lambert, E. G., Hogan, N. L., \& Griffin, M. L. (2007). The impact of distributive and procedural justice on correctional staff job stress, job satisfaction, and organizational commitment. Journal of Criminal Justice, 35(6), 644-656. https://doi.org/ https://doi.org/10.1016/j.jcrimjus.2007.09.001

Lee, C.-K., Song, H.-J., Lee, H.-M., Lee, S., \& Bernhard, B. J. (2013). The impact of CSR on casino employees' organizational trust, job satisfaction, and customer orientation: An empirical examination of responsible gambling strategies. International Journal of Hospitality Management, 33, 406-415. https://doi. org/10.1016/J.IJHM.2012.10.011

Lee, E. M., Park, S.-Y., \& Lee, H. J. (2013). Employee perception of CSR activities: Its antecedents and consequences. Journal of Business Research, 66(10), 1716-1724. https://doi. org/10.1016/J.JBUSRES.2012.11.008

Lii, Y.-S., \& Lee, M. (2012). Doing Right Leads to Doing Well: When the Type of CSR and Reputation Interact to Affect Consumer Evaluations of the Firm. Journal of Business Ethics, 105(1), 69-81. https://doi.org/10.1007/s10551-011-0948-0

Maheshwari, S., \& Yadav, R. S. (2015). Is CSR a Hygiene Factor for Prospective Employees? An Indian Exploration. Indian Journal of Industrial Relations, 50, 601-612. https://doi. org/10.2307/24547007

Mahoney, L. S., Thorne, L., Cecil, L., \& LaGore, W. (2013). A research note on standalone corporate social responsibility reports: Signaling or greenwashing? Critical Perspectives on Accounting, 24(4-5), 350-359. https://doi.org/10.1016/J. CPA.2012.09.008

Málovics, G., Csigéné, N. N., \& Kraus, S. (2008). The role of corporate social responsibility in strong sustainability. The
Journal of Socio-Economics, 37(3), 907-918. https://doi. org/10.1016/J.SOCEC.2006.12.061

Marin, L., Ruiz, S., \& Rubio, A. (2009). The Role of Identity Salience in the Effects of Corporate Social Responsibility on Consumer Behavior. Journal of Business Ethics, 84(1), 65-78. https://doi.org/10.1007/s10551-008-9673-8

McAuliffe, E., Manafa, O., Maseko, F., Bowie, C., \& White, E. (2009). Understanding job satisfaction amongst mid-level cadres in Malawi: the contribution of organisational justice. Reproductive Health Matters, 17(33), 80-90. https://doi.org/ https://doi.org/10.1016/S0968-8080(09)33443-6

Michaelis, B., Stegmaier, R., \& Sonntag, K. (2009). Affective Commitment to Change and Innovation Implementation Behavior: The Role of Charismatic Leadership and Employees' Trust in Top Management. Journal of Change Management, 9(4), 399-417. https://doi.org/10.1080/14697010903360608

Mohr, L. A., Webb, D. J., \& Harris, K. E. (2001). Do Consumers Expect Companies to be Socially Responsible? The Impact of Corporate Social Responsibility on Buying Behavior. Journal of Consumer Affairs, 35(1), 45-72. https://doi. org/10.1111/j.1745-6606.2001.tb00102.x

Morgan, R. M., \& Hunt, S. D. (1994). The Commitment-Trust Theory of Relationship Marketing. Journal of Marketing, 58(3), 20-38. https://doi.org/10.1177/002224299405800302

Nguyen, T. H. (2020). Impact of Leader-Member Relationship Quality on Job Satisfaction, Innovation and Operational Performance: A Case in Vietnam. Journal of Asian Finance, Economics and Business, 7(6), 449-456. https://doi. org/10.13106/jafeb.2020.vol7.no6.449

Ouyang, Z., Sang, J., Li, P., \& Peng, J. (2015). Organizational justice and job insecurity as mediators of the effect of emotional intelligence on job satisfaction: A study from China. Personality and Individual Differences, 76, 147-152. https://doi.org/https:// doi.org/10.1016/j.paid.2014.12.004

Park, S. H., Lee, P. J., Lee, B. K., Roskams, M., \& Haynes, B. P. (2020). Associations between job satisfaction, job characteristics, and acoustic environment in open-plan offices. Applied Acoustics, 168, 107425. https://doi.org/https://doi. org/10.1016/j.apacoust.2020.107425

Pérez-Rodríguez, V., Topa, G., \& Beléndez, M. (2019). Organizational justice and work stress: The mediating role of negative, but not positive, emotions. Personality and Individual Differences, 151, 109392. https://doi.org/https://doi. org/10.1016/j.paid.2019.04.047

Raub, S., \& Blunschi, S. (2014). The Power of Meaningful Work. Cornell Hospitality Quarterly, 55(1), 10-18. https://doi. org/10.1177/1938965513498300

Rice, R. W., Phillips, S. M., \& McFarlin, D. B. (1990). Multiple discrepancies and pay satisfaction. Journal of Applied Psychology, 75(4), 386-393. https://doi.org/10.1037/00219010.75.4.386

Rupp, D. E., Ganapathi, J., Aguilera, R. V, \& Williams, C. A. (2006). Employee reactions to corporate social responsibility: 
an organizational justice framework. Journal of Organizational Behavior, 27(4), 537-543. https://doi.org/10.1002/job.380

Rupp, D. E., Shao, R., Thornton, M. A., \& Skarlicki, D. P. (2013). Applicants' and Employees' Reactions to Corporate Social Responsibility: The Moderating Effects of First-Party Justice Perceptions and Moral Identity. Personnel Psychology, 66(4), 895-933. https://doi.org/10.1111/peps. 12030

Rupp, D. E., Wright, P. M.,Aryee, S., \& Luo, Y. (2015). Organizational Justice, Behavioral Ethics, and Corporate Social Responsibility: Finally the Three Shall Merge. Management and Organization Review, 11(1), 15-24. https://doi.org/10.1017/mor.2015.8

Turban, D. B., \& Greening, D. W. (1997). Corporate social performance and organizational attractiveness to prospective employees. Academy of Management Journal, 40(3), 658-672.

van den Brink, D., Odekerken-Schröder, G., \& Pauwels, P. (2006). The effect of strategic and tactical cause-related marketing on consumers' brand loyalty. Journal of Consumer Marketing, 23(1), 15-25. https://doi.org/10.1108/07363760610641127

Walsh, G., Mitchell, V.-W., Jackson, P. R., \& Beatty, S. E. (2009). Examining the Antecedents and Consequences of Corporate Reputation: A Customer Perspective. British Journal of Management, 20(2), 187-203. https://doi.org/10.1111/j.14678551.2007.00557.x

Williams, R. J., \& Barrett, J. D. (2000). Corporate Philanthropy, Criminal Activity, and Firm Reputation: Is There a Link? Journal of Business Ethics, 26(4), 341-350. https://doi. org/10.1023/A:1006282312238
Wiyono, W. (2010). Keadilan Organisasional Dan Kepuasan Kerja: Pengujian Keterkaitan Equity Theory Dengan Work Outcomes. Benefit: Jurnal Manajemen Dan Bisnis, 13(2), 1-15.

Wong, R., \& Millington, A. (2014). Corporate social disclosures: a user perspective on assurance. Accounting, Auditing \& Accountability Journal, 27(5), 863-887. https://doi.org/10.1108/ AAAJ-06-2013-1389

Wong, Y.-T., Ngo, H.-Y., \& Wong, C.-S. (2006). Perceived organizational justice, trust, and OCB: A study of Chinese workers in joint ventures and state-owned enterprises. Journal of World Business, 41(4), 344-355. https://doi.org/https://doi. org/10.1016/j.jwb.2006.08.003

Wulani, F. (2007). The effect of distribution, procedural and interactional justice on student consumer satisfaction in Surabaya. Jurnal Widya Manajemen \& Akuntansi, 7(1), 84-97.

Yang, H.-C., \& Kim, Y.-E. (2018). The Effects of Corporate Social Responsibility on Job Performance: Moderating Effects of Authentic Leadership and Meaningfulness of Work. Journal of Asian Finance, Economics and Business, 5(3), 121-132. http:// doi.org/10.13106/jafeb.2018.vol5.no3.121

Yusoff, H., Mohamad, S. S., \& Darus, F. (2013). The Influence of CSR Disclosure Structure on Corporate Financial Performance: Evidence from Stakeholders' Perspectives. Procedia Economics and Finance, 7, 213-220. https://oi.org/10.1016/ S2212-5671(13)00237-2 